\title{
Safety of Vehicles Operating on Natural Gas \\ ${ }^{1}$ Larisa M. Gabsalikhova, ${ }^{2}$ Gulnaz R. Sadygova, ${ }^{3}$ Irina V. Makarova \\ ${ }^{1-3}$ Kazan Federal University \\ Email: muhametdinoval@mail.ru
}

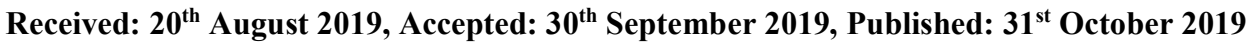

\begin{abstract}
Improvement of efficiency and environmental friendliness of transport is one of the main directions of the transition to a low-carbon economy. In turn, the transfer of vehicles to gas engine fuel will reduce harmful emissions into the atmosphere. "Industry 4.0" involves the rational use of natural and technical resources, the most efficient energy conservation, the recycling of all waste and the receipt of new goods, raw materials or energy from them. The fact that the transition to Industry 4.0 implies the effectiveness of a system for maintaining vehicles in a technically sound condition is equally important. The technical condition of gas-fueled vehicles shall meet the requirements of the technical conditions and instructions of the manufacturers. The article proposes the use of the FMEA analysis method for planning measures to improve the quality and safety of technical maintenance of gas equipment for truck vehicles. Using the FMEA analysis method, we obtained the factors that affect the process of maintenance of gas vehicles. Thus, the practical application of the FMEA analysis method allows reducing, eliminating and preventing failures in the power supply system of gas equipment, and, consequently, increasing the reliability and safety of gas vehicle operation.
\end{abstract}

\section{Keywords}

Safety, Gas Vehicles, Environmental Friendliness, Service

\section{Introduction}

Industry 4.0 involves the rational use of natural and technical resources, the most efficient energy saving. The transport sector is one of the most energy-intensive sectors with the highest emissions. Through the use of alternative fuels, it is possible to reduce the dependence of the economy on hydrocarbons, which is especially important for the transport sector; negative pressure on the environment by fulfilling the UNECE environmental requirements.

The fleet of gas engine machines is constantly growing. It is observed the occurrence of both abnormal emergencies and an increase in the danger of operation, including during road traffic accidents, during the operation of gas engine equipment with its direct participation. According to statistics, a significant number of accidents with severe consequences are associated with the unsatisfactory technical condition of vehicles. The observance of the maintenance regulations for vehicles and gas equipment is of great importance.

\section{Methods}

\section{Transition Terms to Environmental Friendly Transport}

Climate change issues force the government around the world to develop and define policy to address greenhouse gas emissions when transport is recognized as one of the main sources of air pollution [1]. Environmental reasons are the main motives for using natural gas vehicles in Europe [2, 3]. The studies [4] showed lower specific emissions of nitrogen oxides (NOx) from natural gas engines equipped with a catalyst compared to diesel engines equipped with particulate filters and SCR system.

Examining the contributions to the air pollution of gasoline vehicles (GV) and diesel vehicles (DV), heavy duty diesel vehicles (HDDV) and non-HDDV, the authors of article [5] conclude that the HDDV contribution to fleet emissions calculated by EFs from the Chinese Road Emission Inventory Guide, were underestimated. The authors of article [6] argue that the main cause of high emissions of passenger light duty gasoline vehicles (LDGV) are catalytic converter malfunctions.

Nevertheless, the transition from the current situation, in which a gasoline vehicle is dominant, shows a high cost compared to a compressed natural gas vehicle [7].

Vehicle manufacturers are increasingly recognizing their role in helping to achieve the goal of a carbon-free economy and reduce oil dependence. Today, Russian manufacturers offer more than 220 gas-powered car models.

Let us consider the structure of sales volumes of KAMAZ gas-powered vehicles in Russia by body type according to the results of 2018 (Fig. 1). 62\% of sales are accounted for special equipment: garbage trucks, shift buses, vacuum cars, truck cranes, flatbed trucks with a crane, mobile laboratories. 


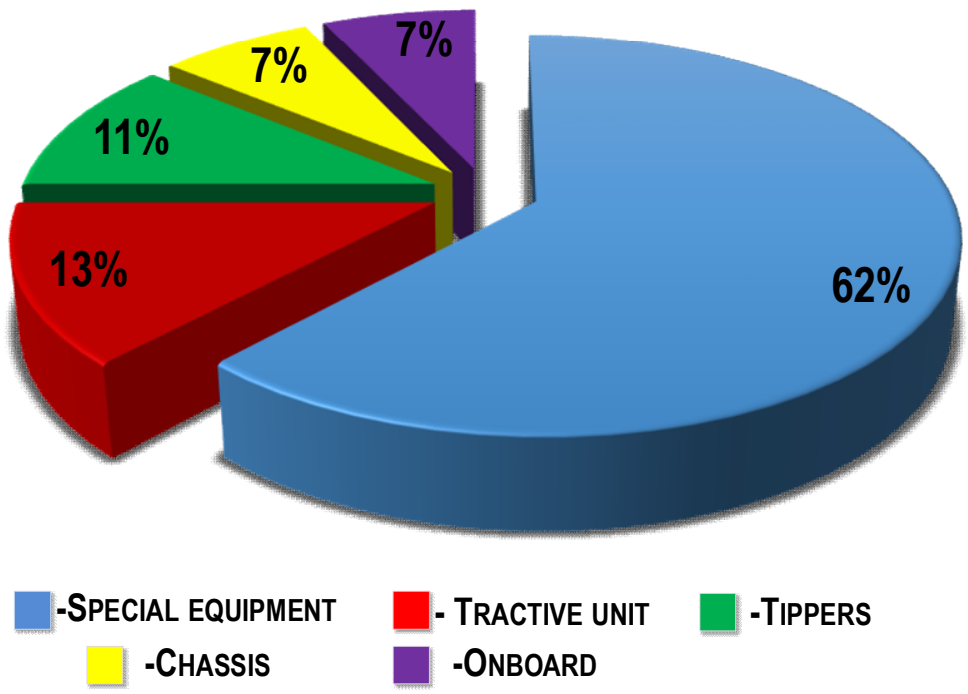

Figure 1: The Structure of Sales Volumes of KAMAZ Gas Vehicles by Body Type

One of the most common vehicles used in the public utilities sector is garbage trucks. In small towns, garbage trucks with side loading of the Arzamas, Mtsensky or Ryazhsky municipal engineering plants are popular, as they are affordable products on the market. [8]. As for the sales of gas-diesel vehicles, they are represented by truck tractors. In 2018, sales of the gas-diesel version of KAMAZ vehicles grew 7.5 times compared to 2017, from 270 to 2010 units. [9].

Organizational and managerial measures as a way to improve the environmental friendliness of vehicles can be divided into those that are taken during transportation planning, the second category of measures is related to the human factor affecting the quality of driving. A number of works $[10,11]$ are devoted to studying the influence of eco-driving on emissions. In the course of research $[12,13]$, the author found that the economic and environmental behavior in the field of eco-driving shows a significant reduction in energy consumption due to a better choice of speed and acceleration speed.

\section{Results and Discussion}

\section{Measures to Ensure Safe Operation of Natural Gas Vehicles}

Vehicle safety has been the subject of a large number of scientific developments. They address the issues of constructive and operational safety of vehicles, such as:

- development and improvement of systems providing the driver with an information about the state of vehicle, hazard warning systems;

- $\quad$ use of computer technology to ensure safety in the system "driver - vehicle - road - environment";

- development and implementation of modern vehicle safety systems;

- $\quad$ implementation of solutions to minimize the effects of road traffic accidents;

- development and implementation of solutions to improve the environmental safety of vehicles.

Currently, the main documents that determine the safety requirements for gas-powered vehicles are: technical regulations of the Customs Union TR/TS [14]; UNECE Regulations No. 110 [15]; UNECE Regulations No. 115 [16].

The main directions of improving the safety of a gas engine vehicle are as follows:

- improvement of the quality of parts, components of gas equipment for vehicles, including engine power systems;

- development of components of gas equipment, provision of automatic shutdown at a mechanical level, with the leakage of gaseous fuel;

- development of algorithms and diagnostic tools to determine gas leakage or malfunction of components of the engine power system at the level of the electronic control unit.

\section{Maintenance of Compressed Natural Gas Vehicles}

When drawing up a maintenance program (MT), operating conditions and environmental influences shall be taken into account. For example, when working in mountainous or hilly areas, brake shoe linings wear out faster, tire cord can be damaged in extreme heat, and garbage trucks that call on a garbage dump station and solid domestic waste landfills often suffer damage typical for off-road driving.

To plan measures to improve the maintenance quality of gas equipment for trucks, it is proposed to apply the FEA (failure modes and effects analysis) analisys method. In the process of FMEA analysis, the causes of problems are divided into key categories. These categories are people, technology, equipment, materials and environment.

The use of the FMEA tool in risk management of new projects in the automotive industry was considered in the studies $[17,18,19]$. As regards the automotive industry, research examines the results of work to assess the impact of potential defects on the operation of automobiles or the manufacturing process of automotive components from the perspective of 
the FMEA methodology. The article [20] considers the use of the PFMEA risk management tool in the supply chain of spare parts.

The article [19] analyzed production failures on the assembly line, which were determined by the GRA approach and minimized using the FMEA method. In a study [21], FMEA analysis was used to analyze the failure of an internal combustion engine. The application of data mining methods and FMEA methods [22] was analyzed in the equipment maintenance system.

All factors for the FMEA analysis were analyzed and ranked by the degree of influence of gas vehicles on the maintenance process. The result of ranking the consequences and reasons for the insufficiently high quality of technical maintenance is presented in Table 1.

\begin{tabular}{|c|c|c|c|c|c|c|}
\hline Potential discrepancy & Aftermath & $\mathrm{S}$ & Causes of potential violation & $\mathrm{O}$ & $\mathrm{D}$ & RPN \\
\hline \multirow{11}{*}{$\begin{array}{l}\text { Insufficient GBE } \\
\text { maintenance quality }\end{array}$} & \multirow{2}{*}{$\begin{array}{l}\text { threat to consumer } \\
\text { safety }\end{array}$} & \multirow{2}{*}{10} & $\begin{array}{l}\text { Non-compliance with maintenance } \\
\text { technology }\end{array}$ & 3 & 3 & 90 \\
\hline & & & $\begin{array}{l}\text { Insufficient capacity for a quality } \\
\text { technology process }\end{array}$ & 7 & 3 & 210 \\
\hline & \multirow{6}{*}{$\begin{array}{l}\text { reduced customer } \\
\text { satisfaction due to } \\
\text { financial losses }\end{array}$} & \multirow{6}{*}{7} & Inadequate staff qualifications & 2 & 3 & 60 \\
\hline & & & Insufficient staff motivation & 3 & 3 & 90 \\
\hline & & & Incomplete staffing & 2 & 1 & 20 \\
\hline & & & Insufficient lighting in the workstatios & 1 & 2 & 20 \\
\hline & & & $\begin{array}{l}\text { Violation of temperature and humidity } \\
\text { conditions }\end{array}$ & 2 & 2 & 40 \\
\hline & & & $\begin{array}{l}\text { Insufficient cleanliness and order in the } \\
\text { workstatios }\end{array}$ & 2 & 2 & 40 \\
\hline & \multirow{3}{*}{$\begin{array}{l}\text { Reduction of the } \\
\text { company's image, } \\
\text { loss of trust in the } \\
\text { brand }\end{array}$} & \multirow{3}{*}{7} & Outdated equipment & 3 & 3 & 90 \\
\hline & & & Late provision of inventory items & 6 & 3 & 180 \\
\hline & & & Low quality of supplied spare parts & 5 & 3 & 150 \\
\hline
\end{tabular}

Table 1: Matrix of FMEA Analysis of the Maintenance System for Gas Vehicles

As can be seen from Table 2, the following factors have the greatest impact on the quality of technical maintenance: untimely provision of inventory items (goods and materials); poor quality of supplied parts; inadequate process capabilities.

To identify opportunities for improving the technological process, we studied the potential types of defects in gas equipment arising from the vehicle operation car in the range of 25-30 ths. km, as well as their consequences for the safety and comfort of the consumer. The data were obtained in the production and technical service of one of the enterprises servicing and operating municipal vehicles using gas engine fuel [23]. The results of the FMEA analysis are presented in Table 2. Due to numerous complaints regarding the failure of gas dispensers, gas valves and phase sensors (Figure 2) and their high priority risk numbers for defects (Table 2), the verification of these elements of the gas power system shall be added to the technological process of the first maintenance MT-1 during the main operation period. Gas dispensers and phase sensors are recommended to be diagnosed by the Askan-10 tester programmer.

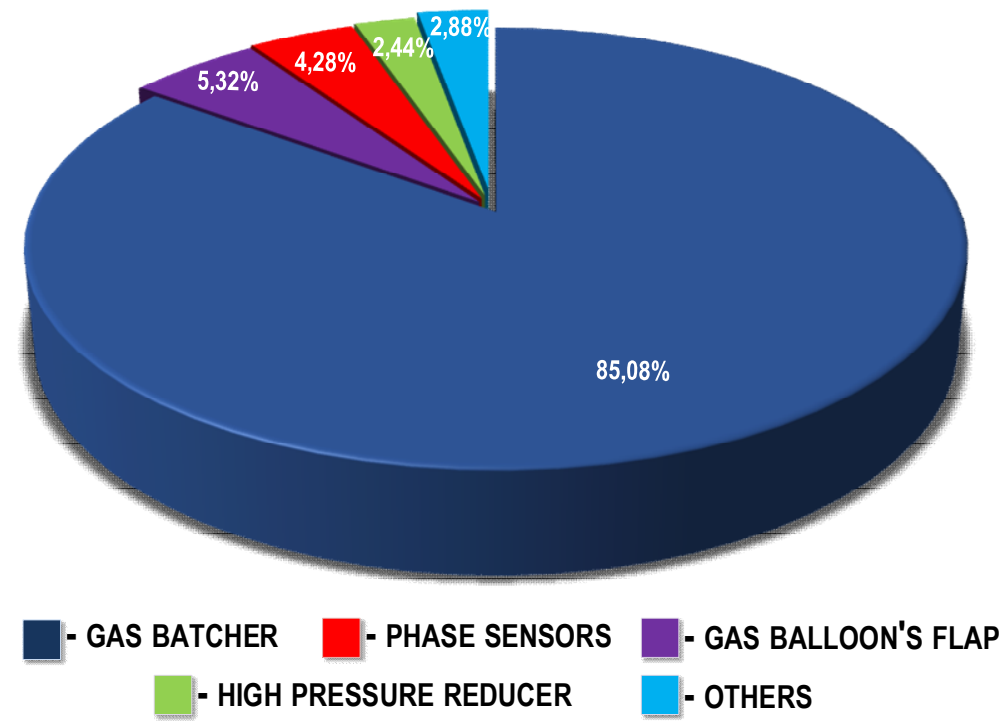

Figure 2: The Percentage of Complaints on Gas Equipment 


\begin{tabular}{|c|c|c|c|c|c|c|c|}
\hline No. & Process & Possible defect & Consequences & $\mathrm{S}$ & $\begin{array}{l}\text { Detection } \\
\text { measures }\end{array}$ & $\mathrm{D}$ & RPN \\
\hline 1 & $\begin{array}{l}\text { Checking the } \\
\text { tightness of gas } \\
\text { equipment and its } \\
\text { connections }\end{array}$ & $\begin{array}{l}\text { Breach impermeability of } \\
\text { gas equipment and its } \\
\text { connections }\end{array}$ & $\begin{array}{l}\text { Fire and explosion } \\
\text { hazard }\end{array}$ & 10 & Leak detector & 1 & 70 \\
\hline 2 & $\begin{array}{l}\text { Checking the } \\
\text { fastening of gas } \\
\text { cylinders on the } \\
\text { bracket }\end{array}$ & Loose cylinder mounting & $\begin{array}{l}\text { Axial displacement and } \\
\text { turning cylinders. Loss } \\
\text { of cylinders. Tube } \\
\text { rupture }\end{array}$ & 9 & $\begin{array}{l}\text { Visual } \\
\text { inspection }\end{array}$ & 1 & 90 \\
\hline 3 & $\begin{array}{l}\text { Checking the } \\
\text { condition of gas } \\
\text { pipelines }\end{array}$ & Damage to gas pipelines & Leak of gas & 9 & $\begin{array}{l}\text { Visual } \\
\text { inspection }\end{array}$ & 1 & 90 \\
\hline 4 & $\begin{array}{l}\text { Check to flaps of } \\
\text { refueling cross-piece }\end{array}$ & $\begin{array}{l}\text { Rod rotates with } \\
\text { jamming }\end{array}$ & $\begin{array}{l}\text { Gas leakage when } \\
\text { filling cylinders }\end{array}$ & 9 & $\begin{array}{l}\text { Visual } \\
\text { inspection }\end{array}$ & 1 & 90 \\
\hline 5 & $\begin{array}{l}\text { Check high pressure } \\
\text { reducer }\end{array}$ & $\begin{array}{l}\text { Sharp decrease in } \\
\text { pressure at the exit from } \\
\text { a reducer }\end{array}$ & $\begin{array}{l}\text { Insufficient fuel supply. } \\
\text { Difficult engine start }\end{array}$ & 7 & $\begin{array}{l}\text { Tescan } \\
\text { programmer } \\
\text { Askan-10 } \\
\end{array}$ & 2 & 98 \\
\hline 6 & Gas meter check & $\begin{array}{l}\text { Jamming dispenser } \\
\text { Dispenser's } \\
\text { Electromagnet Failure }\end{array}$ & $\begin{array}{l}\text { Significant deviation of } \\
\text { the composition of the } \\
\text { air-fuel mixture. } \\
\text { Insufficient fuel supply. } \\
\text { Difficult engine start }\end{array}$ & 7 & Not checked & 7 & 343 \\
\hline 7 & Phase sensor check & No phase sensor signal & $\begin{array}{l}\text { Minor deterioration of } \\
\text { power indices. Slight } \\
\text { increase in fuel } \\
\text { consumption and } \\
\text { exhaust emissions }\end{array}$ & 6 & Not checked & 7 & 294 \\
\hline 8 & $\begin{array}{l}\text { Cylinder valve } \\
\text { check }\end{array}$ & $\begin{array}{l}\text { Damage to the valve } \\
\text { body Worn O-rings }\end{array}$ & Leak of gas & 9 & Not checked & 7 & 441 \\
\hline
\end{tabular}

Table 2: The FMEA Analysis Matrix Concerning the Maintenance Process of Gas Equipment

The advanced technological process is shown in Figure 3.

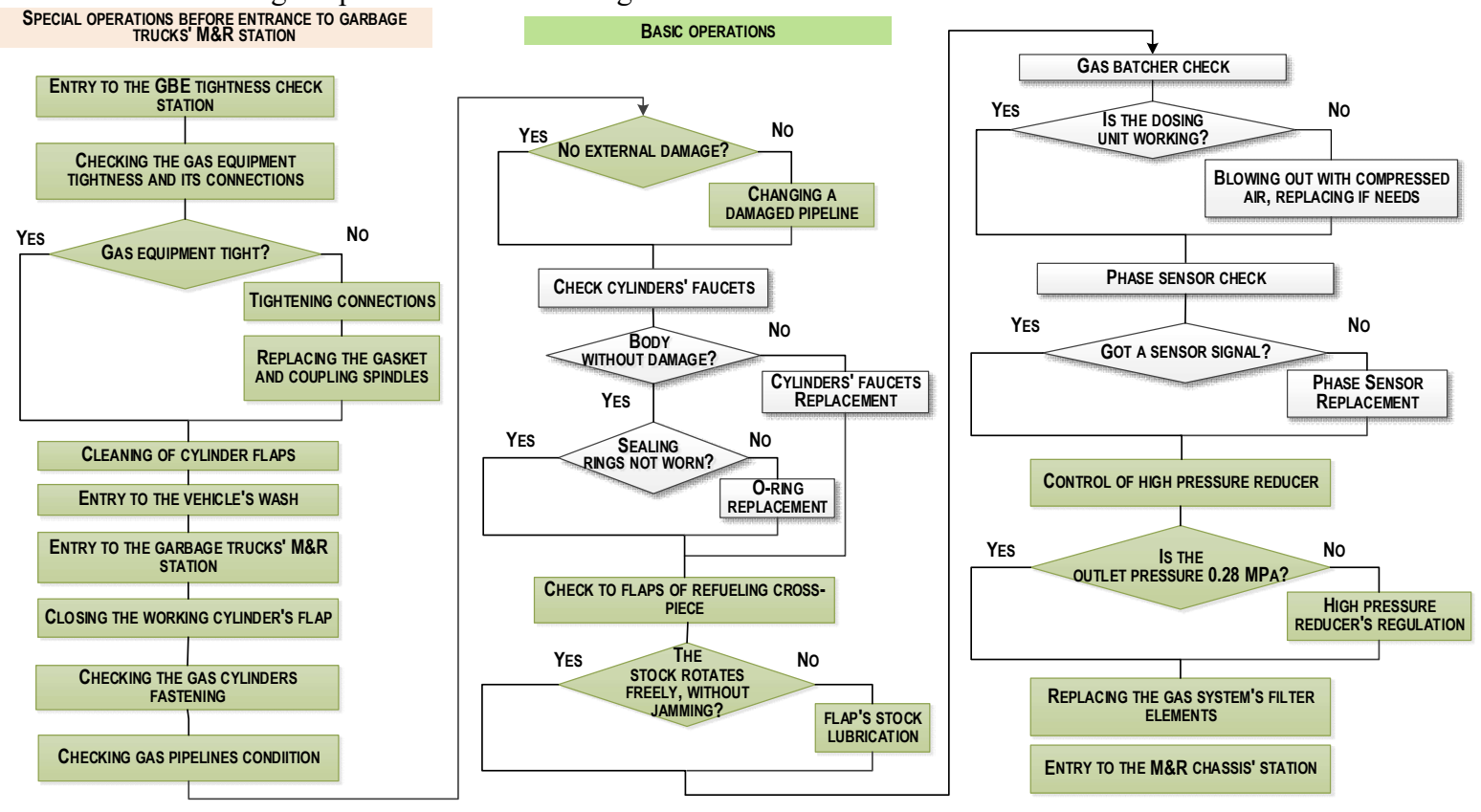

Figure 3: Advanced Technological Process for the Maintenance of Gas Equipment 


\section{Summary}

To plan activities to improve the maintenance quality, it is proposed to apply the FMEA analysis method, aimed at identifying problems in the process of its implementation. The FMEA results served as the basis for adjusting the technological process for the maintenance of gas equipment. This allowed reducing the number of failures in the gas supply system by improving the quality of processes and preventing sudden failures, which increases the reliability and safety of gas communal vehicles.

\section{Conclusions}

Currently, the issues of vehicle safety with natural gas are not only relevant, but become also even more important due to the tightening of the requirements of the Technical Regulations of the Customs Union TR/TS and the UNECE Regulations. The development of systems ensuring the safety of gas powered vehicles shall be directly related to the diagnostics of the electronic components of the engine power system and the electronic engine management system, since the latter include a sufficient number of measuring mechanisms for analyzing gas fuel consumption, its temperature, etc. To improve the quality of service and safety of gas vehicles, the article proposed using the FMEA analysis method for the maintenance system as a whole and the process separately. The analysis revealed the main factors affecting the maintenance quality of gas equipment.

\section{Acknowledgements}

The work is performed according to the Russian Government Program of Competitive Growth of Kazan Federal University.

\section{References}

[1] M.I. Khan, "Identifying and addressing barriers for the sustainable development of natural gas as automotive fuel", International journal of hydrogen energy, no 42, pp. 25453 - 25473, 2017.

[2] Hella Engerer, Manfred Horn, "Natural gas vehicles: An option for Europe", Energy Policy, vol. 38, Issue 2, pp. 1017-1029, 2010.

[3] David C. Quiros, Jeremy Smith, Arvind Thiruvengadam, Tao Huai, Shaohua, "Greenhouse gas emissions from heavy-duty natural gas, hybrid, and conventional diesel on-road trucks during freight transport", Atmospheric Environment, vol. 168, pp. 36-45, 2017.

[4] Arvind Thiruvengadam, Marc Besch, Vishnu Padmanaban, Saroj Pradhan, Berk Demirgok, "Natural gas vehicles in heavy-duty transportation-A review", Energy Policy, vol. 122, pp. 253-259, 2018.

[5] Congbo Song, Chao Ma, Yanjie Zhang, Ting Wang, Lin Wu, Peng Wang, Yan Liu, Qian Li, Jinsheng Zhang, Qili Dai, Chao Zou, Luna Sun, Hongjun Mao, "Heavy-duty diesel vehicles dominate vehicle emissions in a tunnel stud in northern China”, Science of the Total Environment, 637-638, pp. 431-442, 2018.

[6] Cheng Huang, Shikang Tao, Shengrong Lou, Qingyao Hu, Hongli Wang, Qian Wang, Li Li, Hongyu Wang, Jian'gang Liu, Yifeng Quan, Lanlan Zhou, "Evaluation of emission factors for light-duty gasoline vehicles based on chassis dynamometer and tunnel studies in Shanghai", China. Atmospheric Environment, no 169, pp. 193-203, 2017.

[7] H.A. Gabbar, R. Bedard, N. Ayoub, "Integrated modeling for optimized regional transportation with compressed natural gas fuel," Alexandria Engineering Journal, no 55, pp. 533-545, 2016.

[8] Equipment for garbage transportation: results and prospects [Electronic resource]. - URL: https://os1.ru/article/18283-tehnika-dlya-perevozki-musora-itogi-i-perspektivy-krugliy-stol-spetsialistov-otrasli

[9] GAS DIESEL KAMAZ-5490-87 (S5) NEO (CNG) [Electronic resource]. - URL: https://kamaz.ru/production/serial/sedelnye-tyagachi/kamaz-5490-s5-neo/

[10] Cindie Andrieu, Guillaume Saint Pierre, "Comparing effects of eco-driving training and simple advices on driving behavior," Procedia - Social and Behavioral Sciences, no 54, pp. 211 - 220, 2012.

[11] Sze-Hwee Ho, Yiik-Diew Wong, Victor Wei-Chung Chang, "What can eco-driving do for sustainable road transport? Perspectives from a city (Singapore) eco-driving programme," Sustainable Cities and Society, no 14, pp. 82-88, 2015.

[12] Felicitas Mensing, Eric Bideaux, Rochdi Trigui, Julien Ribet, Bruno Jeanneret, "Eco-driving: An economic or ecologic driving style?," Transportation Research, Part C 38, pp. 110-121, 2014.

[13] Ryosuke Ando, Yasuhide Nishihori, "A study on factors affecting the effective eco-driving," Procedia - Social and Behavioral Sciences, no 54, pp. 27 - 36, 2012.

[14] Technical regulations of the Customs Union TR TS 018/2011 "On the safety of wheeled vehicles" [Electronic resource]. - URL: http://sudact.ru/law/reshenie-komissii-tamozhennogo-soiuza-ot-09122011-n_19/tr-ts-0182011/

[15] UNECE Regulations No. 110 [Electronic resource]. - URL: http://dokipedia.ru/document/5166006

[16] UNECE Regulations No. 115 [Electronic resource]. - URL: http://dokipedia.ru/document/5166010

[17] Mayara de Melo Paranhos, Stella Jacyszyn Bachega, Dalton Matsuo Tavares, Naiara Faiad Sebba Calife "Application of failure mode and effects analysis for risk management of a project," Systems \& Management, no 11, pp 444-454, 2016.

[18] GALLIKOVÁ Jana, RUMAN František, "Using of technical diagnostics for an analysis of failure causes and consequences of a selected vehicle," Logistyka, no 4, pp. 3296-3301, 2015. 
[19] K Baynal, T Sarı, B Akpınar, "Risk management in automotive manufacturing process based on FMEA and grey relational analysis: A case study," Advances in Production Engineering \& Management, vol. 13, number 1, pp. 69$80,2018$.

[20] Marasova D., Gaspar M, “The risk management within the supply chain as astrategic factor,” Manažment Podnikov, number 2-2 (4), pp. 139-145, 2016.

[21] Poprocký, R., Galliková, J., Stuchlý, V., Volna, P, "FMEA analysis of combustion engine and assignment occurrence index for risk valuation," Diagnostyka, vol. 18, no. 3, pp. 99-105, 2017.

[22] Reza Farahani, Emad Roghanian, Masoud Tavakoli, "Application of Data-Mining and FMEA Techniques in Maintenance System to Improve Equipment Performance," Journal of Basic and Applied Scientific Research, no 2(9), pp. 9282-9288, 2012.

[23] Gas automotive equipment KAMAZ [Electronic resource]. - URL: http://www.kamaz.ru/ru/vehicle/gas/ 